2002s-79

\title{
Slave Prices from Succession and Bankruptcy Sales in Mauritius, 1825-1827
}

\author{
Shirley Chenny, Pascal St-Amour and \\ Désiré Vencatachellum
}

\section{Série Scientifique \\ Scientific Series}

\section{Montréal}

Septembre 2002

(C) 2002 Shirley Chenny, Pascal St-Amour and Désiré Vencatachellum. Tous droits réservés. All rights reserved. Reproduction partielle permise avec citation du document source, incluant la notice (C)

Short sections may be quoted without explicit permission, if full credit, including () notice, is given to the source.
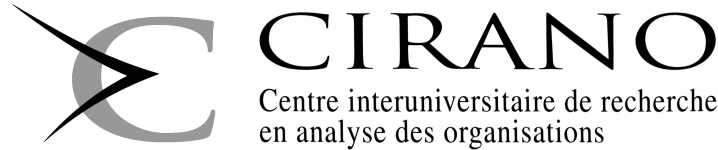

Centre interuniversitaire de recherche en analyse des organisations 


\section{CIRANO}

Le CIRANO est un organisme sans but lucratif constitué en vertu de la Loi des compagnies du Québec. Le financement de son infrastructure et de ses activités de recherche provient des cotisations de ses organisationsmembres, d'une subvention d'infrastructure du ministère de la Recherche, de la Science et de la Technologie, de même que des subventions et mandats obtenus par ses équipes de recherche.

CIRANO is a private non-profit organization incorporated under the Québec Companies Act. Its infrastructure and research activities are funded through fees paid by member organizations, an infrastructure grant from the Ministère de la Recherche, de la Science et de la Technologie, and grants and research mandates obtained by its research teams.

\section{Les organisations-partenaires / The Partner Organizations}

-École des Hautes Études Commerciales

-École Polytechnique de Montréal

-Université Concordia

-Université de Montréal

-Université du Québec à Montréal

-Université Laval

-Université McGill

-Ministère des Finances du Québec

-MRST

-Alcan inc.

- AXA Canada

-Banque du Canada

-Banque Laurentienne du Canada

- Banque Nationale du Canada

- Banque Royale du Canada

-Bell Canada

-Bombardier

-Bourse de Montréal

-Développement des ressources humaines Canada (DRHC)

-Fédération des caisses Desjardins du Québec

-Hydro-Québec

-Industrie Canada

-Pratt \& Whitney Canada Inc.

-Raymond Chabot Grant Thornton

-Ville de Montréal

Les cahiers de la série scientifique (CS) visent à rendre accessibles des résultats de recherche effectuée au CIRANO afin de susciter échanges et commentaires. Ces cahiers sont écrits dans le style des publications scientifiques. Les idées et les opinions émises sont sous l'unique responsabilité des auteurs et ne représentent pas nécessairement les positions du CIRANO ou de ses partenaires.

This paper presents research carried out at CIRANO and aims at encouraging discussion and comment.

The observations and viewpoints expressed are the sole responsibility of the authors. They do not necessarily represent positions of CIRANO or its partners. 


\title{
Slave Prices from Succession and Bankruptcy Sales in Mauritius, 1825--1827*
}

\author{
Shirley Chenny ${ }^{\ddagger}$, Pascal St-Amour $\dagger$ and Désiré Vencatachellum ${ }^{\dagger}$
}

\begin{abstract}
Résumé / Abstract
Nous construisons une base de données unique à partir des ventes de succession et de faillites sur l'Île Maurice afin d'étudier les prix des esclaves entre 1825 et 1827 . Nous trouvons que les hommes, les femmes vendues avec enfants, les esclaves qualifiés et ceux vendus en période de récolte obtiennent les prix les plus élevés. En comparaison, les esclaves avec handicap, ainsi que ceux qui ne sont pas originaires de l'Île Maurice sont vendus moins cher. De plus, la prime pour des jeunes enfants augmente durant la période étudiée. Ceci pourrait indiquer que les propriétaires n'anticipaient pas une abolition prochaine de l'esclavage ou encore pensaient recevoir une compensation financière si l'esclavage était aboli.

We construct a unique data set from succession and bankruptcy sales in Mauritius to investigate the determinants of slave prices between 1825 and 1827. We find that males, females sold with children, skilled slaves and slaves sold during the peak sugar cane harvest season all fetched higher prices. In comparison, handicapped and non-native slaves were sold at a discount. Moreover, the young-children premium increased over the period. This may indicate that slave owners did not think that slavery would be abolished in the near future or thought that they would be compensated in such an event.
\end{abstract}

Mots clés : Esclavage, prix des esclaves, Île-Maurice.

Keywords: Slavery, slave price, Mauritius.

Codes JEL : N37

\footnotetext{
* Corresponding author: Pascal St-Amour, Dept. of Finance, HEC-Montreal, 3000 Cote-Ste-Catherine, Montreal, Quebec, Canada, H3T 2A7. Email: Pascal.St-Amour@hec.ca, tel.: (514) 340-6556, fax: (514) 340-5632. We acknowledge financial support from the FCAR. We are grateful to Ruth Dupré, Paul Lanoie, Mary MacKinnon, and especially Pierre-Thomas Léger for helpful comments. We thank Robert Shell for a stimulating discussion and the staff at Mauritius Archives for their assistance in accessing the notarial acts. All remaining errors are ours.

$\ddagger$ HEC-Montreal, Canada.

$\dagger$ HEC-Montreal, Canada and CIRANO.

$\dagger$ HEC-Montreal, Canada and CIRANO.
} 


\section{Introduction}

The treaty of Capitulation, signed by the French when the British captured Mauritius on December $3^{\text {rd }} 1810$, maintained the French settlers' property rights, including their right to own slaves. However, following the conquest, the British enforced a ban on the import of slaves into the island. Although there is evidence that some slaves were illegally imported afterwards, the illicit trade had subsided by 1820, making the market essentially local (Allen 2001, Valentine 2000). As a result, slaves were either exchanged directly among slave owners or through the secondary market until slavery was abolished in 1835 . This paper focuses on the latter by using succession and bankruptcy sales during public auctions. We study the determinants of slave prices in Mauritius for the years 1825 through 1827.

The bulk of the slavery literature has been concerned with trans-Atlantic trade. For example, recent research focuses on (i) the importance of slavery for colonial powers (Eltis and Engerman 2000), (ii) the impact of slave trade on Africa (Behrendt, Eltis and Richardson 2001, Evans and Richardson 1995, Lovejoy and Richardson 1995), (iii) conditions of shipments (Haines, McDonald and Schlomowitz 2001, Eltis and Richardson 1995) and (iv) market conditions in the Americas (Mancall, Rosenbloom and Weiss 2001, Newland and San Segunda 1996). In contrast, the EastAsian trade in general and the Mauritius trade in particular, have been much less studied by economic historians despite the fact that it was an important slave colony. ${ }^{1}$

An island of 720 square miles in the Indian Ocean, Mauritius had no indigenous population when initially settled by the Dutch in 1638. The first population was composed of Dutch settlers who imported slaves from Madagascar and Indonesia. France occupied the abandoned island in 1715 and rapidly increased the import of slaves from Madagascar, the African East Coast (especially

\footnotetext{
${ }^{1}$ The literature on Mauritian slavery is predominantly from an historical and anthropological, rather than cliometric perspective. Benedict (1980), Teelock (1998), Barker (1996), Valentine (2000) and Allen (2001) provide discussions and bibliographies.
} 
from present-day Mozambique) while a smaller percentage came from India (Pondicherry) and the African West Coast, (Benedict 1980, p. 138). By 1807, nearly 85 per cent of its 78,000 population was composed of slaves (Barker 1996, pp. 53, 168).

Early Nineteenth century Mauritian slavery is also interesting for other reasons. First, because of the ban on imports, a high male sex ratio and a low fertility rate (Valentine 2000, Benedict 1980), the supply of slaves can reasonably be considered as fixed. Consequently, analyzing the determinants of the demand for slaves by studying market prices is possible without having to specify a supply function. Second, changes in attitudes towards slavery following the conquest might have signaled Britain's intention of abolishing slavery in Mauritius. Verifying whether these expectations were reflected in slave prices as early as 1825 is of interest. Third, mothers and children were often sold as a unit. As a result, identifying the value of children slaves in a situation where abolition is pending is also possible.

To study the determinants of slave prices in Mauritius, we construct a unique data set using the notarial acts located at the Mauritius Archives. These acts document the sale of over 1,200 slaves during public auctions. The auctions were publicized at least 3 days in advance (Government of Mauritius 1824, Article $3^{r d}$ ), along with the reasons for the sales. ${ }^{2}$ The transaction data were recorded by a limited number of notaries and contains detailed information on the buyers and sellers, slave characteristics (age, gender, ethnicity, handicaps, qualifications), sales' conditions (bundling, age of children) and date of transaction (Government of Mauritius 1824, Article $7^{\text {th }}$ ).

Our data set presents several advantages. First, market prices rather than appraisals are recorded. As such, they represent true valuations and are not subject to over- and under-reporting biases related to taxes, subsidies, or other distortions. Second, avoiding potential endogeneity prob-

\footnotetext{
${ }^{2}$ For example, in the Mauritius Gazette, no. 60 of May 1826, a sale advertisement stated: “...procédé à la vente à l'encan de 8 têtes d'esclaves, dépendant de la succession de ladite feue Rose Renaud...", i.e. have proceeded with the sale of 8 slaves from the succession of deceased Rose Renaud.
} 
lems associated with bundling of commodities is possible. This occurs because the French legislation governing the sale of slaves prohibited separation of young (impubère) children from their mother. Hence, the potential for strategic bundling of commodities by the owner is limited. Third, the potential bias associated with changes in recording methods is minimized given the limited number of notaries active during slave auctions. As in other slavery economies, purchasing a slave in Mauritius constituted a large investment involving an important degree of information asymmetry. The fact that these exchanges were recorded by notaries gave the information a quasi-legal status under French legal and administrative systems maintained by the British. The precise recording of characteristics and conditions was important to facilitate eventual upholding of transactions by courts (Wahl 1996). Fourth, census data on slaves for 1826 is available. This allows us to confirm the representativeness of our sample.

A fifth and important advantage of our data set is that, as the reasons of the sale are documented, we can focus on a subset of sales in order to limit potential adverse selection biases. Sales following the death or the bankruptcy of an owner are not motivated by 'faulty' characteristics of slaves which might not be observable by the buyer. Moreover, supply can sensibly be characterized as exogenous for these sales. This allows us to focus on the characteristics most sought after by buyers of slaves without having to control for simultaneity biases. The application of a Mincerian pricing equation to study the determinants of market prices is then particularly warranted. We therefore specify a log-linear pricing equation with the slave physical attributes, conditions and time of sale as explanatory variables. We estimate the model for the three years and for each year separately to verify structural stability.

Our main results are the following. First, as in other slave economies, we identify the characteristic concave age-price pattern documented by Fogel and Engerman (1974). Slave prices peak at age levels similar to those found in the US, with females peaking earlier than males. Second, 
male slaves, female slaves sold with children, skilled slaves and slaves sold during the peak sugar cane harvest season all fetched higher prices. In comparison, handicapped and non-native slaves were sold at a discount. Overall, these results may be explained by the nature of slave work in Mauritian sugar plantations (Valentine 2000, Benedict 1980). Physical force and endurance were likely important characteristics sought after by slave owners.

With respect to dynamic factors, we find that slave prices increased substantially in 1827 . Moreover, the value of young children increases over the period. This provides prima facie evidence that slave owners were either not anticipating the abolition of slavery in the near future, or not expecting important capital losses associated with an eventual abolition. This relative optimism can be partly explained by their previous experiences with the colonial authorities. Early talks of abolition following the French Revolution were sternly opposed by Mauritian slave owners who eventually obtained the maintained right to slave ownership under Napoleonic rule. The slavery institutions were also upheld by the British, following fierce resistance to abolition (Burroughs 1976). Mauritian slave owners therefore may have anticipated that they could successfully oppose abolition, or at least be compensated for any subsequent capital loss. In the end, history proved them partially right as they received an important financial compensation while slavery was replaced by restrictive 'apprenticeship' laws which limited the freedom of emancipated slaves.

The remainder of this paper is organized as follows. Section 2 describes the construction of the data set. Section 3 discusses the econometric model and the results. Finally, Section 4 reviews the main findings.

\section{Data Set}

We first summarize the information available in the notarial acts. Next, we present descriptive statistics on our data set, investigating the extent to which the slaves sold during succession sales 
are representative of the slave population. Finally, we present additional statistics on prices and discuss its relation with gender, ethnicity, qualifications and age.

\subsection{Description of the data set}

\subsubsection{Information in the notarial acts}

Our primary source of information is the notarial acts in the General Inventory of Notaries (group NA) which are located at the Mauritius Archives in Coromandel, Mauritius. Table 1 in Appendix B describes the main characteristics of this inventory. Between 1825 and 1827 there were 152 public auctions during which only eight notaries were active. They sold at least 1,299 slaves. $^{3}$ These eight notaries were all active in 1825 and 1826 , while two notaries sold no slave in 1827 . The number of auctions was fairly stable across the three years and was evenly distributed among the notaries, except for Bonnefin who accounts for close to a third of all auctions. However, the number of slaves sold is not different between Bonnefin and Arnaud who each account for 26 and 27 per cent of all slaves sold. Seven of the notaries auctioned in Port Louis, the capital of Mauritius and one notary was based in the agricultural district of Flacq.

During an auction, a slave was either sold individually, or as a bundle with other slaves. There were two types of slave bundles. First, a bundle could be composed of slaves of various age and sex. The notary acts contained 25 such bundles sold during these three years for a total of 85 slaves. Since voluntary bundling may be endogenous, we omit these bundles altogether in order to avoid potential endogeneity biases (Heckman 1979). Second and most frequently, a bundle consisted of a mother with her children. Article 47 of Colbert's Code Noir prohibited the separation of young children from their mother. Hence, the bundling of mothers with their children can safely

\footnotetext{
${ }^{3}$ Due to the poor condition of some notarial acts, it is impossible to transcribe some of the recorded information.
} 
be regarded as exogenous. Out of the remaining 1,213 slaves, 24 per cent were mother-children bundles, typically involving two children.

In addition to the selling price (in piastres or livre tournois), most records either stated the slave's gender explicitly, or that information can be inferred from the transaction's phrasing. ${ }^{4}$ Moreover, a slave's age, ethnicity, occupation and the auction date were reported. The notarial acts also documented the reason for selling the slaves. Those reasons and frequency of occurrence are described in Table 2. The most important reason by far was succession sale, followed by voluntary sales and bankruptcies. Voluntary sales are likely to take into consideration market prices, and could be motivated by hidden defects of the slave (Pritchett and Chamberlain 1993, Greenwald and Glasspiegel 1983). In comparison, succession and bankruptcy sales of slaves can be treated as independent of the prevailing market conditions, i.e. slave supply from these sales can be considered as price-inelastic. Because our focus is on the determinants of demand and in order to avoid the adverse-selection biases, we omit the 192 voluntary sales for the rest of the analysis and study the 941 succession and 79 bankruptcy sales. ${ }^{5}$

\subsubsection{Representativeness}

Our sample can be compared to the slave population in order to assess its representativeness. For this purpose, we use the census data in the Greffe de l'Enregistrement des Esclaves in the Mauritius Archives, collected by Vijaya Teelock of the University of Mauritius, compiled and discussed in Valentine (2000). Most of the data is based on the 1826 census and we compare our sample with only these slaves. ${ }^{6}$ The statistics of the census and sample are reported in Table 3.

\footnotetext{
${ }^{4}$ For example, the acts written in French distinguish between vendu (male) and vendue (female).

${ }^{5}$ One act referred to the forced sale of a slave following a two-year imprisonment for physical aggression of the master. Because this sale was ordered by the court and as this information was public at the time of the sale, there is no reason to suspect endogeneity or adverse selection biases. This sale is consequently included in our sample.

${ }^{6}$ Note however that this is a partial census because slaves in the district of Port-Louis are not recorded.
} 
Table 3 reveals that natives (Creoles) form the majority of slaves. This is a result of the ban on slave imports enforced by the British. Slaves from Madagascar and Mozambique are nearly equally represented while a small percentage consists of Indians. On average the racial distribution of slaves in our sample is a good representation of the population distribution.

Our sample differs somewhat from the 1826 census for the male-female ratio. We find that 57 per cent of the slaves are male in the census but this percentage equals 69 in our sample. Males are therefore over-represented in the notarial acts. Nonetheless, our sample has the same age characteristics as those of the slave population. Whether slaves are regrouped by gender or ethnicity, age differences between our sample and the population are negligible and not statistically significant.

Overall we can safely conclude that our sample is representative of the entire slave population. Having described the information recorded in the notarial acts and confirmed its representativeness, we now focus on a statistical description of slave prices.

\subsection{Descriptive statistics on slave prices}

\subsubsection{Gender, occupation, ethnicity: quantities and prices}

Table 4 presents the number of individuals sold in non-bundle sales and average prices of slaves by gender, occupation and ethnicity. We classify occupations into three main categories: Skilled, Agriculture and Sea-related (laborers and other agricultural) and Household (maids and other household). ${ }^{7}$

With respect to quantities, we find that over 75 per cent of female slaves were employed for household service, most often as maids. Only two female slaves were considered as skilled (sack-

\footnotetext{
${ }^{7}$ See the note to Table 4 for a complete description.
} 
makers). The bulk of male slaves worked in agriculture, mainly as laborers (pioches). Nearly 30 per cent of males were considered as skilled, most often as carpenters, followed by masons.

The statistics show that the average price of a male and female slave was 297 piastres $(\$ 293)$ and 251 piastres $(\$ 248)$ respectively. ${ }^{8}$ Thus, it appears that female slaves were sold at a discount compared to males. Results also suggest that independent of gender, Creoles were sold at a premium compared to non-native, particularly Indian, slaves. Finally, we also find a positive human capital premium, i.e. household and skilled slaves were sold at a higher price than agricultural ones.

\subsubsection{Age- - price profiles}

Figure 1 in Appendix A plots realized and fitted age-price profiles for both male and female slaves. As in Fogel and Engerman (1972), realized prices are the average of prices relative to that of a prime-aged (18 to 31 year old) male slave for each calendar year in our sample. Fitted prices are obtained by regressing prices on a third-degree polynomial in age. The age-price profile displays the familiar bell-curved pattern identified in other slave economies (Newland and San Segunda 1996, Moreno, Klein and Engerman 1983). We find that male prices are usually higher at all ages and peak later than female slaves (24 years, vs 23 years). Both male and female peak-price ages are very similar to those found in the US although somewhat younger than for other slavery economies (see Table 5).

Overall, we conclude that gender, ethnicity, occupation and age appear to determine the price level of Mauritian slaves. Descriptive statistics do not however identify the individual effects on prices of each characteristic as potential correlations across factors are not taken into account. For this purpose, we resort to a multivariate econometric analysis.

\footnotetext{
${ }^{8}$ The exchange rate between the piastre and the British pound was 5 piastres to the $£($ Allen 1999 , p. xvii). The British-US exchange rate for 1827 is $\$ 4.94$ US to the $£$ (Officer 2001).
} 


\section{Multivariate Econometric Analysis}

\subsection{Model}

We mentioned earlier that the use of a Mincerian pricing equation is particularly appropriate when supply can sensibly be considered as price inelastic. Hence, following standard practice (Newland and San Segunda 1996, Kotlikoff 1979), we regress the log of slave prices on the slave's attributes, the characteristics of the sale and the slave's human capital. Moreover, we introduce timing variables and time-varying parameters to capture dynamic and seasonal effects. The econometric model is:

$$
\begin{aligned}
\log \left(P_{i}\right)= & \alpha+\phi_{1} A G E_{i}+\phi_{2}\left(A G E_{i}\right)^{2}+\phi_{3} M A L E_{i}+\phi_{4} H A N D_{i}+\phi_{5} I N D_{i}+\phi_{6} M A L A G_{i} \\
& +\phi_{7} M O Z A M B_{i}+\beta_{1} C H I L D L 5_{i}+\beta_{2} C H I L D O 5_{i}+\tau_{1} A G R I C_{i}+\tau_{2} H_{O U U S} \\
& +\eta_{1} Q 1_{i}+\eta_{2} Q 2_{i}+\eta_{3} Q 3_{i}+\eta_{4} Y 26_{i}+\eta_{5} Y 27_{i}+\epsilon_{i},
\end{aligned}
$$

where, $P_{i}$ is the recorded price, $i$ denotes the slave's identity, $\alpha, \boldsymbol{\phi}, \boldsymbol{\beta}, \boldsymbol{\tau}, \boldsymbol{\eta}$ are parameters and $\epsilon_{i}$ is a white noise error term. The explanatory variables are as follows:

1. Attributes:

(a) AGE Age of slave at period of sale;

(b) $M A L E$ Equals 1 if male, 0 if female;

(c) HAND Equals 1 if handicapped slave, 0 otherwise;

(d) IND Equals 1 if of Indian origin, 0 otherwise;

(e) MALAG Equals 1 if of Malagasy origin, 0 otherwise;

(f) $M O Z A M B$ Equals 1 if of Mozambique origin, 0 otherwise.

2. Bundling: 
(a) CHILDL5 Equals to the number of children less than or equal to 5 year old;

(b) CHILDO5 Equals to the number of children older than 5.

\section{Occupation:}

(a) AGRIC Equals 1 if employed in agriculture, 0 otherwise;

(b) HOUSE Equals 1 if employed in household, 0 otherwise.

4. Time of sale:

(a) $Q J$ Equals 1 if slave sold in $J^{\text {th }}$ quarter, 0 otherwise, where $J=1,2,3$;

(b) $Y X X$ Equals 1 if slave sold in year $18 X X, 0$ otherwise, where $X X=26,27$.

We showed in Section 2.2.2 that the age-price profile was characteristically concave, increasing then decreasing after peak-price age. ${ }^{9}$ Section 2.2.1 highlighted the fact that ethnicity, gender and human capital were apparent determinants of slave prices. Also, given the nature of Mauritian slave work, we expect that handicapped slaves would be sold at a lower price. Furthermore, when considered as long-term productive assets, children should be positively valued by slave buyers. However, rearing costs, low life expectancy and potential abolition reduce the value of infants. The final effect of young children in mother-child bundles is uncertain. Children older than 5 demand less in terms of mother's time, are less likely to die and can contribute to production. We therefore expect a premium for older children in mother-child bundles.

Model (1) is sufficiently flexible to capture timing and structural shifts. First, given that slave production is predominantly agricultural, we introduce seasonal dummies. Our reference quarter is the fourth, which corresponds to the height of sugar cane harvesting. We therefore anticipate a discount on the prices of slaves sold in other quarters. Second, the model can be estimated over

\footnotetext{
${ }^{9}$ We restrict (1) to a second-order polynomial in age because the coefficient on higher-order terms were not significantly different from zero.
} 
the whole sample, or for each year separately. In the latter case, however, we drop the two year dummies. The positive effect on sugar prices of British tariff policies should increase the price of slaves at later dates. However, if abolition is anticipated by slave buyers, we should expect prices to decline over time. Given that the dependent price is the log of prices, year dummies control for potential inflation through fixed effects in the pooled-year sample. On the other hand, a separate estimation for each year allows us to assess whether or not the effect of each variable is constant over time.

Finally, for reasons discussed above, we do not anticipate any endogeneity bias in estimating (1). Hence, the econometric model is adequately estimated by OLS. All standard errors are corrected for potential heteroscedasticy of an unknown form. Moreover, to control for potential biases related to extreme observations, we re-estimate the model using the Least Absolute Deviation and the Trimmed Least Squares estimators, without detectable effect in results.

\subsection{Results}

The estimates of the parameters of (1), their level of significance for a standard $T$-test and the premium (or discount) effect in percentage are reported in Table 6. We start by discussing the results for the whole sample reported in the second and third columns of Table 6 . Overall, the model presents a good fit for observed prices, with an adjusted $R$-squared of 57 per cent with most explanatory variables being significant at the 1 per cent level.

First, regarding physical attributes, we find a concave relationship between age and price. Conrad and Meyer (1958) and Fogel and Engerman $(1972,1974)$ also document this pattern for the US. Using the estimates in Table 6, we find that, on average, a slave's highest price was obtained at age 23. This number is very close to the simple estimates presented in Table 5. 
Second, a male slave fetched a premium of 25 per cent. This estimate is larger than the 9 per cent figure for Southern US (Kotlikoff 1979) and Peru (Newland and San Segunda 1996, full sample), but close to that found for the Peruvian vineyards sub-sample by Newland and San Segunda (1996). Following the ban on imports in Mauritius, slave supply could only have been maintained through reproduction. Hence, an increase in the value of females might have been anticipated, especially since they were outnumbered by males (see Table 3). Nonetheless, we find a strong demand for male slave labor which likely results from the demand for physical force in sugar cane plantations. Indeed, this is confirmed by a hefty discount of 56 per cent on handicapped slaves, a figure that is close to that found by Newland and San Segunda (1996) for Peru. ${ }^{10}$

Third, ethnicity dummy variables confirm the presence of a discount on non-native slaves, especially Indians. For Cuba, Moreno et al. (1983) also find that non-native slaves are sold at a lower price. Native slaves had the advantage of being better adapted to conditions in Mauritius and less subject to illness and marronage. On the other hand, Indians were of significantly smaller size than other slaves (Valentine 2000, Fig. 13, p. 36) and therefore of likely lower physical force.

With respect to bundling, we find that slave buyers significantly valued children when they were purchased with their mother. Buyers of slave children were clearly not expecting a large capital loss on their investment in the near future. An infant younger than 5 year old fetched a premium of 25 per cent, whereas this premium increased to 52 per cent if older. Kotlikoff (1979) also finds that slave bundle prices increase with the age of children for the New Orleans market. Low birth rates, widespread practices of abortion by slaves and high mortality at birth (Benedict 1980, Valentine 2000) probably explain why the premium on a living child is so high. Moreover, the important increase in this premium after age 5 likely reflects high mortality rates of children aged 1 to 5 as well as the rearing costs to the mother in terms of foregone output.

\footnotetext{
${ }^{10}$ Newland and San Segunda (1996) find a point estimate of 0.65 for 'healthy' dummy, corresponding to a 91 per cent premium. The 'non-healthy' discount is therefore $-91 / 191$, or 48 per cent.
} 
With respect to occupation, we find that skilled slaves fetched a premium of 14 per cent compared to agricultural slaves and of 17 per cent compared to household slaves. These premia are lower than those found for the US and for Peru (Kotlikoff 1979, Newland and San Segunda 1996, find a skill premium varying between 43 and 46 percent). Nonetheless, human capital was valued positively by slave owners despite Mauritius being an agricultural economy. Two reasons may explain this result. First, Mauritius had an important rental market for slaves. Hence, regardless of occupation, urban slaves could be rented out to plantation owners, especially during the sugar cane harvest season. Therefore, as for other slaves, skilled slaves were also mobile across occupations. Moreover, the demand for skilled slaves reflects the isolation of the island from the metropoles. Long journeys between Europe and the Indian Ocean implied that Mauritius had to develop local production of houses, clothing, shoes, ..., rather than relying exclusively on manufactured imports from colonial powers. The flexibility and local demand for output produced by skilled slaves therefore explain their positive price premium.

The time at which the sale took place is also interesting. A price increase of 11 to 18 per cent is found if the sale occurred in the fourth quarter. This indicates a strong seasonal component, with peak prices coinciding with the sugar cane harvest. A similar pattern is identified for the US by Kotlikoff (1979). With respect to the year of sale, we find that slaves prices in 1826 were not significantly different from those in 1825 , whereas prices rose by 44 per cent in 1827 compared to 1825 . Furthermore, contrasted to other years, 1827 is characterized by (i) a lower discount on handicapped slaves, (ii) lower ethnic discounts and (iii) a more pronounced seasonality. These factors all point towards less discriminating buyers in a peak year in slave demand and is likely a delayed consequence of the 1825 British equalization of import duties. Indeed, between 1825 and 1827, Mauritian sugar production nearly doubled from 10,869 to 20,309 metric tons (Paturau 1988, Table 8.3, p. 88). Mauritian slave price increases are also consistent with price increases 
found elsewhere; Lovejoy and Richardson (1995, Table 2, p.108) find that real slave prices along the Atlantic Coast of Africa increased by 41 per cent between 1821-25 and 1826-30. The cost of adjusting production to increase sugar exports could explain the two-year lag.

Perhaps the most interesting finding is that the value of young children increases between 1825 and 1827. Indeed, an expected abolition of slavery ceteris paribus reduces an investment's time horizon used in calculating the net discounted expected value of owning a slave and consequently, the maximum price a slave buyer is willing to pay. An increase in the price of slaves in general and of children in particular, is therefore not consistent with pending abolition. We can think of two possible explanations for this result. The first one is that slave buyers in 1825-27 did not anticipate the 1835 abolition, despite the enforcement of the 1807 slave trade ban by the British in Mauritius after its conquest.

A second explanation is that slave owners expected to be compensated for any capital loss if slavery was abolished. Efficient markets would have internalized this belief into higher prices than in the absence of compensation. Earlier successes by slave owners in fighting off French and British attempts to abolish slavery (Burroughs 1976) might have enhanced confidence in their lobbying efficiency. Slave buyers could have anticipated that they would receive compensation if abolition occurred. In hindsight, the slave owners' optimism seems somewhat justified; an overall compensation of over $£ 2 \mathrm{M}$ for a total slave population of about 60,000 was paid in 1835 by the British government to Mauritian owners of slaves. The compensation was granted for any slave aged 6 and higher. Moreover, emancipated slaves remained tied to their master for a period of 6 years under a restrictive apprenticeship system. Both elements would have been consistent with a maintained demand for slaves. Whether this compensation was sufficient to explain the increase in prices is left to further research. 


\section{Conclusion}

This paper analyzes the determinants of slave prices in Mauritius 1825, 1826 and 1827. We construct a unique data set from the notarial acts in the Mauritian archives. Given a ban on imports enforced by the British and the use of succession and bankruptcy sales, we can reasonably consider the supply of slaves as fixed. A further considerable advantage is the availability of the 1826 partial census on Mauritian slaves which reveals that the notarial acts data is representative of the slave population.

Overall, our estimates identify a concave age-price profile as well as a significant discount on female and non-native (especially Indian) slaves. Interestingly, the presence of children was valued by the market, in particular for children older than 5 . Moreover, we identify a positive premium on human capital despite Mauritius being an agricultural economy. In addition, we find a strong seasonal component coinciding with seasonal elements in sugar cane production. Finally, we find that once other factors are accounted for, the price of young children increased sharply over the period. This last result could be explained by either slave owners' disbelief that slavery would be abolished or by a correct anticipation of compensation in the event of slavery abolition.

Overall, Mauritian slavery displays interesting similarities and differences with other slave systems of the Nineteenth century. The valuation of physical force, of reproductive potential and seasonal components in demand is also found in American slavery. It differs, however, in sources of slave supply, legislation, relative isolation, and history of relations with metropolitan authorities on the subject of slavery. Hopefully, the quality of the Mauritian data will warrant further research on this topic and help towards a better understanding of slavery. 


\section{References}

Allen, Richard B. (1999) Freedmen, and Indentured Laborers in Colonial Mauritius (Cambridge: Cambridge University Press)

- (2001) 'A traffic of several nations: the Mauritian slave trade, 1721-1835.' In History, memory and identity, ed. Vijaya Teelock and Edward A. Alpers (University of Mauritius: Centre for African Studies)

Barker, Anthony J. (1996) Slavery and antislavery in Mauritius, 1810-33: the conflict between economic expansion and humanitarian reform under British rule (Houndmills: MacMillan)

Behrendt, Stephen D., David Eltis, and David Richardson (2001) 'The costs of coercion: African agency in pre-modern Atlantic world.' Economic History Review 54(3), 454-76

Benedict, Burton (1980) 'Slavery and incenture in Mauritius and Seychelles.' In Asian and African systems of slavery, ed. James L. Watson (Oxford: Basil Blackwell) chapter 6, pp. 135-68

Burroughs, Peter (1976) 'The Mauritius rebellion of 1832 and the abolition of British colonial slavery.' Journal of Imperial and Commonwealth History 4(3), 243-65

Conrad, Alfred H., and John R. Meyer (1958) 'The economics of slavery in the antebellum South.' Journal of Political Economy 66, 95-122

de Mello, Pedro C. (1992) 'Rates of return on slave capital in Brazilian coffee plantations, 1871-1881.' In Without consent or contract: the rise and fall of American slavery: markets and production: technical papers, ed. Robert W. Fogel and Stanley L. Engerman, vol. 1 (New York: W.M. Norton) pp. 63-79

Eltis, David, and David Richardson (1995) 'Productivity in the transatlantic slave trade.' Explorations in Economic History 32(4), 465-84

Eltis, David, and Slanley L. Engerman (2000) 'The importance of slavery and the slave trade to industrializing Britain.' Journal of Economic History 60(1), 123-44 
Evans, E.W., and David Richardson (1995) 'Hunting for rents: the economics of slaving in pre-colonial Africa.' Economic History Review 48(4), 665-86

Fogel, Robert W., and Stanley L. Engerman (1972) 'The market evaluation of human capital.' Note presented at the Annual Cliometrics Conference, Madison Wisconsin

- (1974) Time on the cross: The economics of American Negro slavery (Boston, Mass.; Toronto, Ont.: Little Brown)

Government of Mauritius (1824) Recueil des Lois, Proclamations, Notes et Avis du Gouvernement (Île Maurice: Imprimerie de Mallac, Fils et Frères). Lieutenant-General, The Honorable Sir Galbraith Lowry Cole, Governor and Commander In Chief of the Island of Mauritius and Dependencies

Greenwald, Bruce C., and Robert R. Glasspiegel (1983) 'Adverse selection in the market for slaves: New Orleans, 1830-1860.' Quarterly Journal of Economics 98(3), 479-99

Haines, Robin, John McDonald, and Ralph Schlomowitz (2001) 'Mortality and voyage length in the Middle Passage revisited.' Explorations in Economic History 38(4), 503-33

Heckman, James (1979) 'Sample selection bias as a specification error.' Econometrica 47, 153-61

Kotlikoff, Laurence J. (1979) 'The structure of slave prices in New Orleans, 1804 to $1862 . '$ Economic Inquiry 17(4), 496-518

- (1992) 'Quantitative description of the New Orleans slave market, 1804 to 1862.' In Without consent or contract: the rise and fall of American slavery: markets and production: technical papers, ed. Robert W. Fogel and Stanley L. Engerman, vol. 1 (New York: W.M. Norton) pp. $31-53$

Lovejoy, Paul E., and David Richardson (1995) 'British abolition and its impact on slave prices along the Atlantic coast of Africa, 1783-1850.' Journal of Economic History 55(1), 98-119 
Mancall, Peter C., Joshua L. Rosenbloom, and Thomas Weiss (2001) 'Slave prices and the South Carolina economy, 1722-1809.' Journal of Economic History 61(3), 616-39

Moreno, Fraginals, Hubert Klein, and Stanley L. Engerman (1983) 'The level and structure of slave prices on Cuban plantations in the Mid-Nineteenth century: some comparative perspectives.' American Historical Review 88(5), 1201-18

Newland, Carlos, and Maria Jesus San Segunda (1996) 'Human capital and other determinants of the price life cycle of a slave: Peru and La Plata in the eighteenth century.' Journal of Economic History 56(3), 694-701

Officer, Lawrence H. (2001) 'Exchange rate between the United States dollar and the British pound, 1791-2000.' Economic History Services, EH.Net. http://www.eh.net/hmit/exchangerates/pound.php

Paturau, J. Maurice (1988) Histoire économique de l'île Maurice (Les Pailles, Île Maurice: Henry \& Cie.)

Pritchett, Jonathan B., and Richard M. Chamberlain (1993) 'Selection in the market for slaves: New Orleans, 1830-1860.' Quarterly Journal of Economics 108(2), 461-73

Teelock, Vijaya (1998) Bitter sugar: sugar and slavery in 19th century Mauritius (Moka, Mauritius: Mahatma Gandhi Institute)

Valentine, Barbara (2000) 'The dark soul of the people: slaves in Mauritius.' Working Paper 0102, Rhodes University. South African Data Archive

Wahl, Jenny B. (1996) 'The jurisprucence of American slave sales.' Journal of Economic History 56(1), 143-69 


\section{A Figures}

Figure 1: Age-Price Profile

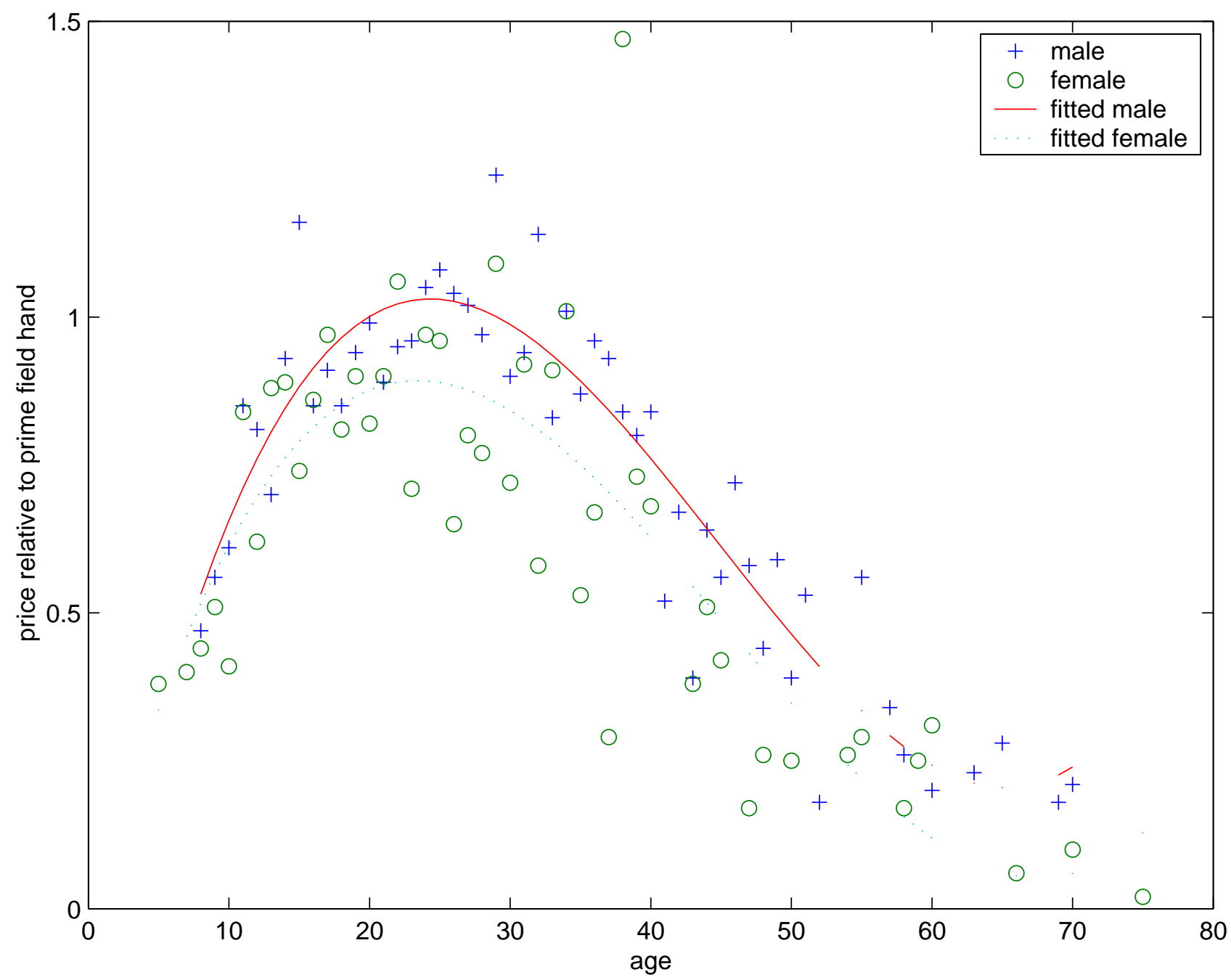

Note: Prices are slave price $P_{i}$ divided by the price of a male prime-aged male slave $P_{p a}$. Fitted age-price profiles from:

$$
P_{i} / P_{p a}=\alpha+\phi_{1} A G E_{i}+\phi_{2}\left(A G E_{i}\right)^{2}+\phi_{3}\left(A G E_{i}\right)^{3}+u_{i}
$$




\section{B Tables}

Table 1: Distribution of Slaves Sold and Auctions by Notary and Year of Sale

\begin{tabular}{|c|c|c|c|c|c|c|c|c|}
\hline \multirow{2}{*}{$\begin{array}{l}\text { Archive } \\
\mathrm{nb} \text {. }\end{array}$} & \multirow[b]{2}{*}{ Notary } & \multirow[b]{2}{*}{ Vols. } & \multirow[b]{2}{*}{ District } & \multirow{2}{*}{$\begin{array}{r}\text { Slaves sold } \\
1825-27 \\
\end{array}$} & \multicolumn{4}{|c|}{ Number of Auctions } \\
\hline & & & & & $1825-27$ & 1825 & 1826 & 1827 \\
\hline NA69 & ARNAUD, Charles M.A & $1-26$ & Port-Louis & 336 & 15 & 6 & 5 & 4 \\
\hline NA71 & BÉLIN, Jean & $1-4$ & Port-Louis & 33 & 5 & 1 & 4 & 0 \\
\hline NA72 & BONNEFIN, Alexandre & $1-25$ & Port-Louis & 354 & 48 & 13 & 15 & 20 \\
\hline NA73 & BONSERGENT, Théodore & $1-3$ & Port-Louis & 43 & 17 & 6 & 7 & 4 \\
\hline NA68 & BUSSIÉ, Jean-Paul & $1-20$ & Port-Louis & 163 & 23 & 9 & 4 & 10 \\
\hline NA63 & DUBOR, Louis-Joseph Senoni & $1-16$ & Port-Louis & 185 & 18 & 9 & 4 & 5 \\
\hline NA67 & JOLLIVET, Yves Isidore & $1-24$ & Port-Louis & 105 & 20 & 5 & 5 & 10 \\
\hline NA66 & MONTOCCHIO, Charles Jean & $1-30$ & Flacq & 80 & 6 & 3 & 3 & 0 \\
\hline & & & total & 1299 & 152 & 52 & 47 & $\overline{53}$ \\
\hline
\end{tabular}

Table 2: Notary Acts: Reasons for the Sale of Slaves

\begin{tabular}{lrr} 
Reason for the sale & Number slaves & Per Cent \\
\hline Succession & 941 & $77,6 \%$ \\
Voluntary sale by owner & 192 & $15,8 \%$ \\
Bankruptcy & 79 & $6,5 \%$ \\
\hline Total & 1212 & $100.0 \%$
\end{tabular}


Table 3: Slave 1826 Population and 1825-27 Notarial Acts Comparison

\begin{tabular}{lrrrr|rrrr} 
& \multicolumn{3}{c}{ Number of slaves } & \multicolumn{4}{c}{ Age of slaves } \\
& 1826 Census & \multicolumn{2}{c}{ Notarial acts } & 1826 Census & Notarial acts \\
& number & $\%$ & number & $\%$ & average & std. & average & std. \\
\hline All sample & 20,467 & 100 & 918 & 100 & 24.9 & 14.3 & 26.2 & 14.5 \\
\hline Creole & 10,364 & 51 & 445 & 48 & 17.1 & 12.1 & 16.9 & 12.2 \\
Madagascar & 3,666 & 18 & 172 & 19 & 30.5 & 11.3 & 32.4 & 9.9 \\
Mozambique & 5,581 & 28 & 259 & 28 & 33.6 & 10.8 & 35.1 & 10.3 \\
India & 669 & 3 & 42 & 5 & 44.1 & 12.6 & 44.1 & 10.1 \\
\hline Male & 11,671 & 57 & 609 & 66 & 26.3 & 14.0 & 27.6 & 13.8 \\
Female & 8,762 & 43 & 309 & 34 & 23.1 & 14.5 & 23.4 & 14.5
\end{tabular}

Note: Census data is taken from Greffe de l'Enregistrement des Esclaves in the Mauritius Archives. Notarial acts data refers to succession sales sub-sample. 
Table 4: Number, Prices, Gender, Occupations and Ethnicity of Slaves: Individual Sales Only Gender Occupation Creole Mozambique Madagascar Indian Total

\begin{tabular}{|c|c|c|c|c|c|c|c|c|c|c|c|}
\hline & & Nb. & Price & Nb. & Price & $\mathrm{Nb}$. & Price & $\mathrm{Nb}$. & Price & Nb. & Price \\
\hline \multirow[t]{6}{*}{ Female } & Skilled & & & & & 2 & 71 & & & 2 & 71 \\
\hline & Laborer & 13 & 320 & 9 & 210 & 3 & 190 & 3 & 65 & 28 & 243 \\
\hline & Other agric. & & & & & & & & & & \\
\hline & Maid & 35 & 263 & 1 & 51 & 5 & 203 & & & 41 & 250 \\
\hline & Other household & 24 & 295 & 9 & 243 & 12 & 279 & 5 & 106 & 50 & 263 \\
\hline & Total & 72 & 284 & 19 & 217 & 22 & 231 & 8 & 90 & 121 & 251 \\
\hline \multirow[t]{6}{*}{ Male } & Skilled & 32 & 465 & 49 & 325 & 50 & 329 & 3 & 136 & 134 & 355 \\
\hline & Laborer & 29 & 297 & 81 & 241 & 33 & 294 & 2 & 213 & 145 & 264 \\
\hline & Other agric. & 9 & 338 & 33 & 272 & 12 & 269 & 6 & 140 & 60 & 268 \\
\hline & Maid & 44 & 291 & 11 & 266 & 10 & 264 & 2 & 132 & 67 & 278 \\
\hline & Other household & 14 & 376 & 12 & 252 & 8 & 365 & 9 & 161 & 43 & 294 \\
\hline & Total & 128 & 348 & 186 & 271 & 113 & 309 & 22 & 154 & 449 & 297 \\
\hline \multirow[t]{6}{*}{ Total } & Skilled & 32 & 465 & 49 & 325 & 52 & 319 & 3 & 136 & 136 & 351 \\
\hline & Laborer & 42 & 304 & 90 & 238 & 36 & 286 & 5 & 124 & 173 & 261 \\
\hline & Other agric. & 9 & 338 & 33 & 272 & 12 & 269 & 6 & 140 & 60 & 268 \\
\hline & Maid & 79 & 278 & 12 & 248 & 15 & 244 & 2 & 132 & 108 & 267 \\
\hline & Other household & 38 & 325 & 21 & 248 & 20 & 314 & 14 & 141 & 93 & 277 \\
\hline & Total & 200 & 325 & 205 & 266 & 135 & 296 & 30 & 137 & 570 & 287 \\
\hline
\end{tabular}

Note: Prices are recorded in current piastres. Exchange rate, 5 piastres $=£ 1=\$ 4.94 \mathrm{US}$ in 1827. Skilled: Assistant blacksmith, barrel maker, blacksmith, carpenter, carpentry trainee, carter, commander, locksmith, mason, master carpenter, master mason, mattress maker, nailer, roofer, sack-maker, sawyer, shoemaker, squarer, stone cutter, stone cutter trainee, sugar-maker. Agriculture: Chief gardener, gardener, laborer, marketman, stable-boy, watchman and sea-related activities: caulker, fisherman, sailor. Household: Baker, cook, innkeeper, laundress, maid, messenger, nurse, seamstress, shoe polisher, tailor.

Table 5: A Comparison of Maximum-Price Age Level

\begin{tabular}{lccc} 
Author & Country & Male & Female \\
\hline & & & \\
Moreno et al. (1983) & Cuba & $28-30$ & 25 \\
de Mello (1992) & Brazil & $26-27$ & 22 \\
Newland and San Segunda (1996) & Peru & $28-29$ & $25-26$ \\
Kotlikoff (1992) & US & 25 & 23 \\
Chenny, St-Amour and Vencatachellum (2002) & Mauritius & 24 & 23
\end{tabular}




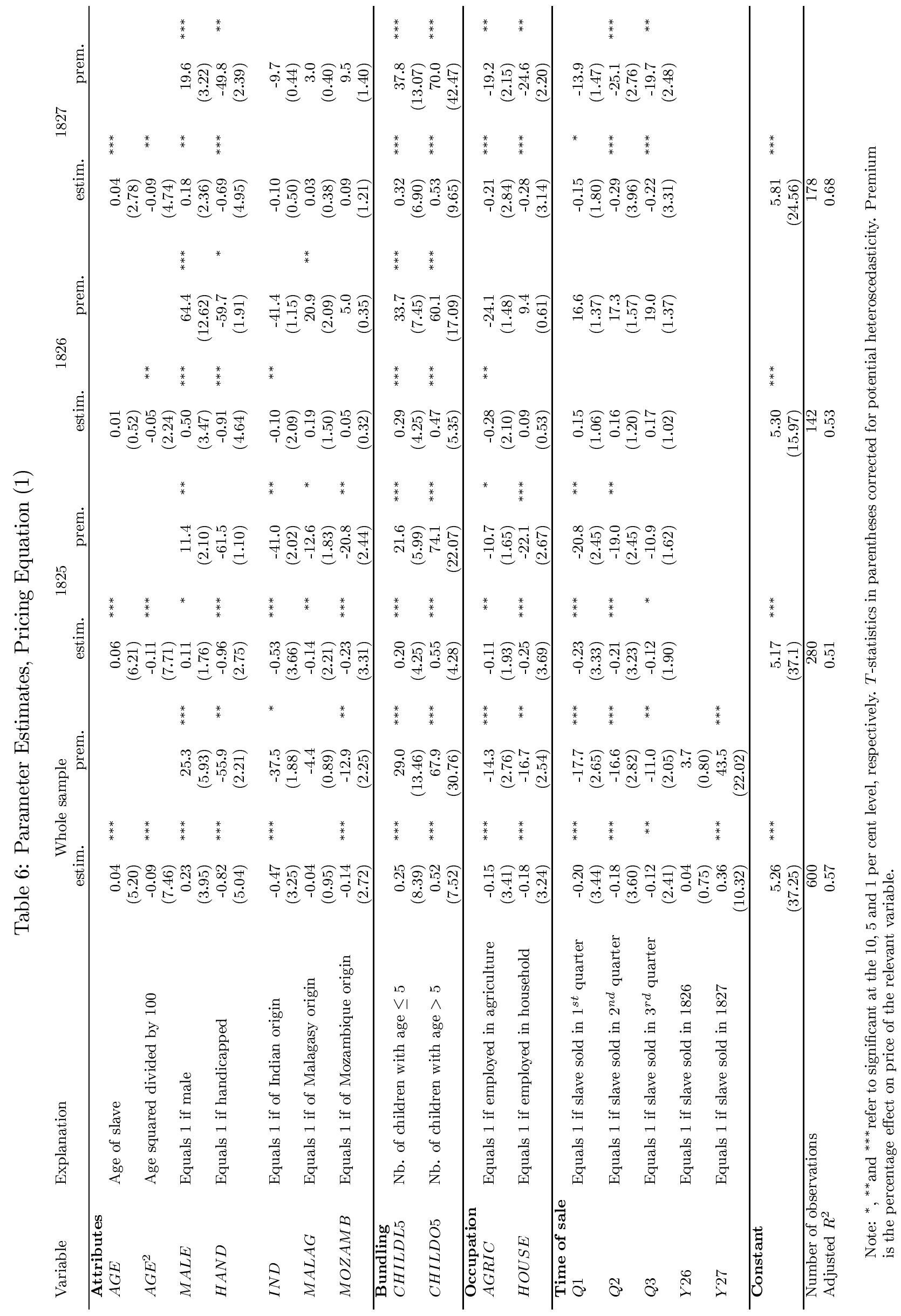

